\title{
Aplikasi Metode Penerjemahan dalam Pembelajaran Kitab Kuning
}

\author{
Ainur Rohmah ${ }^{1^{*}}$ dan Muhammad Muklas ${ }^{2}$ \\ ${ }^{1,2}$ STKIP Nurul Huda \\ *E-mail: ainur82@stkipnurulhuda.ac.id
}

\begin{abstract}
Abstrak
Translation as a process cannot be separated to the activity in foreign language learning despite there is still a controvesial issue abou it. This article aims to describe the translation process in Bandongan and Sorogan Method as the oldest and the best method in teaching and learning "kitab kuning". The data are collected by observing, interviewing and studying of documentation. The writer as an instrument to collect the data attended the teaching and learning process. The data are analyzed by comparing the theory of translation method and the application of bandongan and sorogan method. The result shows that in the bandongan method, the teacher apply the word for word and literal method toward text in kitab kuning and also in sorogan method, the students apply word for word and literal method when they are reading kitab kuning.
\end{abstract}

Kata kunci: translation, bandongan, sorogan, kitab kuning.

\section{PENDAHULUAN}

Aktivitas menerjemah merupakan aktivitas yang tidak dapat dipisahkan dengan kegiatan akademik. Aktvitas ini tidak hanya dilakukan pada mata kuliah tarjamah saja, tetapi pada semua matakuliah ataupun pelajaran jika buku referensi yang digunakan menggunakan bahasa asing atau bahkan buku yang dipelajarinya itu berupa buku bahasa asing.

Bukan tidak terdapat permasalahan dalam penerjemahan. Permasalahan terberat dalam penerjemahan adalah mendapatkan padanan kata antara bahasa sumber dan bahasa sasaran. Menerjemah tidak hanya menguasai bahasa sumber dan bahasa sasaran tapi penerjemah harus memiliki kemampuan pemahaman meyeluruh tentang bidang pengetahuan yang dicakup teks bahasa sumber (BS) tersebut.

Selama ini ada terdapat isu kontaraversial mengenai pengajaran bahasa asing dan penerjemahan yang merupakan komponen penting dalam pengajaran bahsa asing. Lion dalam Pekkanli (2012:955) menyatakan bahwa cara terbaik bagi peserta didik dalam menguasai bahasa asing yang sedang dipelajari adalah dengan menjadi orang asli dari bahasa tersebut bukannya dengan cara menterjemahkan dalam bahasa peserta didik. Sedangkan Pekkanli (2012: 955) dalam penelitiannya berjudul Translation and the Contemporary Language teacher menyatakan bahwa" translation is a communicative activity and that it assists in the development of the learners communicative competence". Lebih lanjut dia mengatakan bahwa menterjemah secara alami menuntut peserta didik untuk berfikir dan berdiskusi sementara guru dapan memilih materi yang mengilustrasikan aspek bahasa yang dianggap sulit oleh peserta didik dan mengatasi kesulitan ini dengan cara mendiskusikan dalam bahasa ibu. Sementara itu Collin (1993:31) dalam Pekkanli mengatakan bahwa menterjemah dapat membantu pemerolehan bahasa kedua (bahasa asing) karena menterjemah menggunakan materi yang otentik, interaktif, berpusat pada siswa dan memunculkan otonomi peserta didik. Hal ini tentunya sangat berkaitan dengan pola aktivitas menterjemah itu sendiri. Memperkuat pernyataan bahwa menterjemah merupakan aktivitas yang komunikatif, Çelik\& Ozcan (2013: 289) mengatakan bahwa dalam proses menterjemah, penterjemah mengawali aktivitanya dengan proses memahami (comprehension) lalu menganalisis (analysis) dan dilanjutkan pada proses mengulang atau memperhatikan keseluruhan teks (rephrasing) sehingga dihasilkan teks terjemahan yang dapat dipahami dalam bahasa target. 
Penerjemahan sebagai suatu subjek pelajaran tidak pernah dimaktubkan dalam kurikulum bahasa asing atau bahasa daerah di sekolah dasar atau pendidikan menegah. Hal ini dikarenakan penerjemahan tidak berhubungan dengan proses pembelajaran bahasa untuk receptiveskill (reading dan listening) atau productiveskill (speaking dan writing). Seperti unngkapan Basnett (2002:8):

Translation today is perceived as an interdisciplinary field of study and the invisible connection between language and way of life has become a focal point of scholarly attention

"...for translation is not just the transfer of texts from one language into another, it is now

rightly seen as a process of negotiation between texts and between cultures".

Penerjemahan bukan hanya pengalihan bahasa pada teks dari bahasa yang satu dengan bahasa yang lain, melainkan penerjemahan belakangan ini merupakan proses negosiasi antara teks yang diterjemahkan dan antara budaya yang tersirat pada tek sumber dan teks tujuan. Ilmu penerjemahan merupakan suatu cakupan besar dimana tidak hanya kosakata, tata bahasa, faktor sosial dan budaya yang perlu diketahui, melainkan bisa juga merupakan suatu cakupan studi pos-kolonialisme. Hal ini terkait dengan pendapat dari Robinson (2007:1) yang berbunyi Penerjemahan merupakan suatu keahlian alih bahasa yang tidak hanya menekankan aspek isi teks dan konteks budaya, melainkan bagaimana sejarah budaya dan ekonomi dalam suatu teks terimplikasi. Dengan kata lain penerjemahan yang menuntut pemahaman yang luas dari si penerjemah untuk dapat dikuasai tidak mungkin dilakukan oleh peserta didik sekolah dasar atau menengah.

Penerjemahan merupakan suatu keterampilan yang harus diasah terus menerus; juga, penerjemahan harus dilakukan dengan mengasah kemampuan peserta didik untuk bisa mendeteksi kesalahan dalam bahasa: "(1) that there is no substitute for practical experience - to learn how to translate one must translate, translate, translate - and (2) that there is no way to accelerate that process without damaging students' ability to detect errors in their own work". (Robinson, 2007: 1). Sementara itu menurut Munday (2008:25) proses penerjemahan antara dua bahasa tulis yang berbeda melibatkan penerjemah mengubah teks asli (teks sumber) dalam bahasa verbal asli (bahasa sumber) ke dalam suatu teks tertulis (teks tujuan) dalam bahasa verbal yang berbeda (bahasa tujuan).

Istilah translation dalam bahasa Inggris memiliki beberapa makna yang merujuk pada bidang subjek umum, produk (teks yang telah diterjemahkan) atau proses (tindakan yang menghasilkan terjemahan, yang dikenal dengan penerjemahan). Seperti pernyataan Hatim \& Munday (2004:3) bahwa translation sebagai produk berpusat pada produk yang dihasilkan oleh penterjemah (translator). Sedangkan translation sebagai proses fokus terhadap peran penterjemah dalam mengambil teks asli/teks sumber dan mengubahnya dalam bahasa lain/bahasa sasaran. Dalam artikel ini kata translation dimaknai sebagai suatu proses bukannya suatu produk. Ada beberaepa definisi penerjemahan terkait dengan suatu proses. Brislin (1976:1) mengemukakan pendapatnya mengenai penerjemahan sebagai proses pengalihan pesan dan ide dari bahasa sumber ke bahasa sasaran, tidak peduli apakah dalam bentuk tulisan atau bukan tulisan, sudah memiliki sistem penulisan atau belum, atau apakah salah satu atau kedua bahasa tersebut berbentuk bahasa isyarat. Lebih spesifik Newmark, (1981:7) menyatakan bahw penerjemahan adalah suatu keahlian yang meliputi usaha mengganti pesan atau pernyataan tertulis dalam suatu bahasa dengan pesan atau pernyataan yang sama dalam bahasa lain. Senada dengan Newmark, Nida and Taber (1969: 3) mengatakan penerjemahan merupakan aktivitas untuk menghasilkan sesuatu yang setara dengan alam terdekat dari pesan bahasa sumber ke dalam bahasa penerima, pertama dalam hal makna dan kedua dalam hal gaya.

Dalam proses penerjemahan, penerjemah biasanya menggunakan tidak hanya satu metode saja tetapi beberapa metode sehingga hasil terjemahan tersebut memenuhi kriteria terjemahan yang baik. Ada beberapa metode yang dapat digunakan oleh penterjemah dalam menerjemah. Newmark (1988: 45) menyebutkan ada delapan jenis metode penerjemahan yang dibagi menjadi dua golongan, yaitu berorientasi pada bahasa sumber (BS) dan berorientasi pada bahasa tujuan (BT). Diantara metodemetode tersebut adalah metode kata demi kata/word for word dan metode harfiah/literal. Penerjemahan kata demi kata/word for word translation dilakukan dengan menerjemahkan kata demi kata dan 
membiarkan susunan kalimat seperti dalam sumber. Metode ini biasanya menerjemahkan secara baris per baris dengan BT langsung dibawah kata-kata BS. Penerjemahan ini yang paling dekat dengan bahasa sumber. Disini urutan kata dalam teks bahasa sumber tetap dipertahankan, kata-kata diterjemahkan dengan maknanya yang paling dasar diluar konteks. Kata-kata yang bermuatan budaya diterjemahkan secara harfiah. Kegunaan terjemahan kata demi kata adalah untuk memahami mekanisme bahasa sumber atau untuk menafsirkan teks yang sulit sebagai proses awal penerjemahan

Contoh:

BS : Look, little guy, you all shouldn't be doing that.

BT : Lihat, anak kecil, kamu semua harus tidak melakukan itu.

Sedangkan penerjemahan harfiah/literal translation dilakukan dengan mengubah struktur kalimat namun kata dan gaya bahasa masih dipertahankan. Berbeda dengan metode yang di atas, dalam metode ini konstruksi gramatikal BS di konversi ke padanan BT terdekatnya, tetapi kata-kata leksikal diterjemahkan secara tunggal diluar konteks. Kontruksi gramatikal bahasa sumber dikonversikan ke dalam padanannya (bahasa sasaran), sedangkan kata-kata diterjemahkan di luar konteks. Sebagai proses penerjemahan awal penerjemahan harfiah dapat membantu melihat masalah yang harus diatasi.

Contoh:

BS : look, little guy, you all shouldn't be doing that.

BT : lihat, anak kecil, kamu semua seharusnya tidak melakukan itu

Istilah penerjemahan pedagogis muncul terkait dengan penerjemahan dan proses pembelajaran. Istilah ini dimaknai sebagai penerjemahan untuk mengalih bahasakan item-item bahasa yang sulit dalam proses pembelajaran bahasa seperti aspek bahasa atau hal-hal yang terkait dalam proses presentasi bahasa dari guru kepada peserta didik.

Proses penerjemahan tidak dapat dipisahkan dengan proses pembelajaran bahasa dan pembelajaran selain bahasa suatu contoh pembelajaran kitab kuning. Kitab kuning adalah kumpulan hasil pemikiran para ulama terdahulu. Hal ini sejalan dengan pendapat berikut. "Secara umum kitab kuning dipahami oleh beberapa kalangan sebagai kitab referensi keagamaan yang merupakan produk pemikiran para ulama pada masa lampau yang ditulis dengan format khas pra-modern, sebelum abat ke-17-an M."(PD Pontren, 2008:95).

Dalam proses pembelajaran kitab kuning terdapat dua metode yang sejak dahulu sampai sekarng digunakan dalam lingkungan Pondok Pesantren, yaitu bandongan dan sorogan. Metode bandongan atau juga dikenal dengan istilah wetonan merupakan suatu metode seperti kuliah dimana peserta didik mengikuti proses belajar dan pembeajaran dengan cara duduk dihadapan guru/ustad yang menerangkan kitab dan peserta didik menyimak kitab mereka masing-masing sembari memaknai kitab tersebut serta membuat catatan penting dari setiap keterangan guru (Dep.Agama RI, 2003:39).

Dalam metode bandongan sekelompok murid (5-500) orang mendengarkan seorang guru membaca, menerjemahkan, menerangkan dan seringkali mengulas buku-buku Islam dalam bahasa arab (Wahid, 1999: 280). Dalam proses pembelajaran dengan metode ini guru/ustad membacakan kitab kuning yang tercetak dalam bahasa arab. Kitab kuning ini ada yang tercetak lengkap dengan harkatnya dan ada yang tanpa harkat atau yang disebut kitab gundul. Guru membacanya dengan mengikuti kaidah tata bahasa arab (nahwu shorof) kemudian menerjemahkannya, yang biasanya dalam bahasa jawa, lalu menjelaskannya. Sementara itu peserta didik menulis makna/arti tiap kata yang dibaca dalam bahasa jawa juga dengan cara menuliskan makna tersebut tepat dibawah kata arabnya, biasanya dalam posisi miring guna mengefesienkan tempat, beserta kode tata bahasanya. Dari paparan tersebut, dilihat dari sisi guru dapat diketahui bahwa proses penerjemahan terjadi dalam metode bandongan/wetonan. Sementara dari sisi peserta didik dapat dilihat bahwa mereka harus menguasai ilmu tata bahasa juga beserta kode tata bahasanya selain itu metode ini membutuhkan ketelitian peserta didik/santri dalam menyimak dan ngesahi (menuliskan makna tepat dibawah kata 
secara rapi dan efisien).

Berbeda dengan metode bandongan, metode sorogan memposisikan peserta didik sebagai pembaca kitab kuning sedangkan guru mendengarkannya. Syukri (2005:73) mengatakan bahwa kata sorogan berasal dari bahasa jawa yaitu sorog yang berarti menyodorkan kitab kepada gurunya. Dalam metode ini, peserta didik/santri secara individu menghadap kepada gurunya dengan membawa kitab mereka kemudian membacanya dengan melalui proses yang sama dengan bandongan yaitu membaca, menterjemah/memberi makna dan menjelaskannya. Sementara guru mendengarkan dan menegur peserta didik tersebut jika ada kesalahan dalam penggunaan tata bahasanya karena hal tersebut akan mempengaruhi makna/arti yang akan diberikan pada tiap kata yang ada. Dalam metode ini guru dapat mengetahui dengan pasti kemampuan peserta didiknya.

Proses pemberian makna/arti tiap kata atau frase dalam metode bandongan dan sorogan pada umumnya dilakukan dengan menggunakan bahasa Jawa. Namun sedikit berbeda yang terjadi di Pondok Pesantren Nurul Huda. Di sini proses pemaknaan kata atau frase terkadang dilakukan dalam bahasa Indonesia mengingat tidak semua santri di pesantren ini adalah orang jawa walaupun pesantren ini merupakan basis orang Jawa. Hal ini dipelopori oleh Pimpinan Pondok Pesantren ini dengan alasan (1) pesan atau pelajaran yang ada dalam kitab bisa sampai ke santri dengan baik, (2) menghormati suku yang tidak memahami bahasa jawa dan (3) sebagai daya tarik tersendiri bagi pesantren ini.

Kitab kuning dan pondok pesantren adalah dua sisi mata uang yang tak terpisahkan, jika ada pondok pesantren tanpa kitab kuning ibarat lubuk tanpa ikan. Pondok pesantren sendiri adalah salah satu lembaga pendidikan yang ada di Indonesia yang memiliki peran yang besar dalam perkembangan pendidikan.

\section{METODE}

Penelitian ini merupakan penelitian studi kasus. Studi kasus merupakan pendekatan penlitian kualitatif dimana peneliti fokus terhadap satu kajian yang diketahui sebagai sistem yang terikat (Gay, Mills \& Airasian,2012: 443). Dalam penelitian ini, peneliti menyelidiki secara cermat suatu program, peristiwa, aktivitas, proses, atau sekelompok individu. Menurut Gay dkk (2012:445), studi kasus digunakan ketika peneliti ingin menjawab pertanyaan deskriptif ( apa yang terjadi) atau pertanyaan penjelasan (bagaiamana/kenapa sesuatu itu terjadi). Dalam penelitian ini, peneliti menyelidiki aktivitas yang berlangsung dalam pengajaran kitan kuning dengan menjawab pertanyaan bagaimana proses penterjemahan itu terjadi dalam metode bandongan dan sorogan.

Pengumpulan data dilakukan dengan cara observasi, wawancara dan analisis dokumentasi berupa kitab kuning yang telak diberi makna (diasahi). Peneliti sebagai instrurnen penelitian, dapat menyesuaikan cara pengumpulan data dengan masalah dan lingkungan penelitian, serta dapat mengumpulkan data yang berbeda secara serentak.

\section{HASIL DAN PEMBAHASAN}

\section{Kitab Taisiril Khalaq}

Kitab Taisiril Kholaq berbentuk kecil seukuran buku tulis dan terjilid kuat layaknya buku tulis juga. Kitab ini memiliki warna kertas putih walaupun disebut kitab kuning. Jarak antar baris dua spasi yang memungkinkan peserta didik (santri) leluasa memberi makna tepat di bawahnya. Layaknya buku cetakan resmi, kitab ini lengkap juga dengan nama pengarang, judul, tahun terbit, penerbit serta kota tempat penerbitan. Taisiril Kholak berisi tentang akhlak/adab/tata karma dalam besosialisasi baik dalam keluarga, sekolah dan masyarakat. santri yang mengaji kitab ini duduk di level sekolah menengah atas yaitu kelas XI dan XII. Dapat disimpulkan penentuan kitab di dasarkan atas tingkat kesulitan kitab tersebut untuk dikaji pada level-level tertentu.

\section{Metode Pembelajaran}

Sistem pengajaran kitab ini dilakukan dengan bandongan dan sorogan. Dalam bandongan guru 
membaca kitab tersebut kata perkata ataupun frase perfrase sementara itu santri mendengarkannya serta menulis arti/makna yang diucapkan guru tepat dikata yang dibaca guru serta menambahkan penjelasan disekitar kata ataupun frase yang dibaca. Di sini guru tidak hanya membaca dan member makna tetapi lebih pada penjelasan bab tersebut dikaitkan dengan keadaan sekarang. Contoh-contoh yang diambil oleh guru adalah situasi yang ada saat ini sehingga isi kitab lebih mudah dipahami peserta didik.

Pada gambar.1 proses penterjemahan dalam pembacaan kitab kuning. Proses tersebut menunjukkan bahwa setiap pembahasan di awali dengan judul yang mensuratkan isi dari teks tersebut. Pada judul terlihat kode gramatikal berupa huruf mim. Kode gramatikal ini menjelaskan kedudukan/fungsi dari kata tersebut. Mim disini singkatan dari mubtadak yang menandakan bahwa frase tersebut adalah frase nominal dalam bahasa Inggris Noun Phrase. Kode mim tersebut dibaca utawi. Dilihat pada tulisan dibawahnya yang memakali bahasa Jawa pegon terbaca kata-kata: iki, kode hurufkho, bab, kode huruf jim, hak dan wong tuo. Secara literal dua kata tersebut memiliki arti hak dan orang tua. Tetapi dalam pemaknaannya terlihat banyak kode yang terlibat. Hal ini menandakan penggunaan gramatikal guna memperoleh makna yang jelas. Proses ini menunjukkan aktivitas penerjemahan word for word dan literal.

Frase ini jika dibaca secara bandongan jawa pegon (word for word) akan berbunyi " huququl walidaini utawi iki iku bab nerangake piro-piro hak e wong tuo loro" versi indonesianya adalah " huququl walidaini yaitu bab yang menerangkan beberapa hak kedua orang tua". Jadi sebenarnya ada proses ellipsis (kata haadha baabun) dalam kalimat tersebut ketika harus menjadi sebuah judul namun pada pengartiannya masih dipakai elipsisis tersebut. Secara singkat menjadi "piro-piro hak e wong tuo loro". Secara literal menjadi piro-piro hak e wong tuo. Frase tersebut secara Indonesia dapat diucapkan dengan "Hak-Hak Orang Tua". Hak-hak disini lebih menekankan pada hak-hak perlakuan. Dengan kata lain tata krama anak terhadap orang tuanya sendiri.

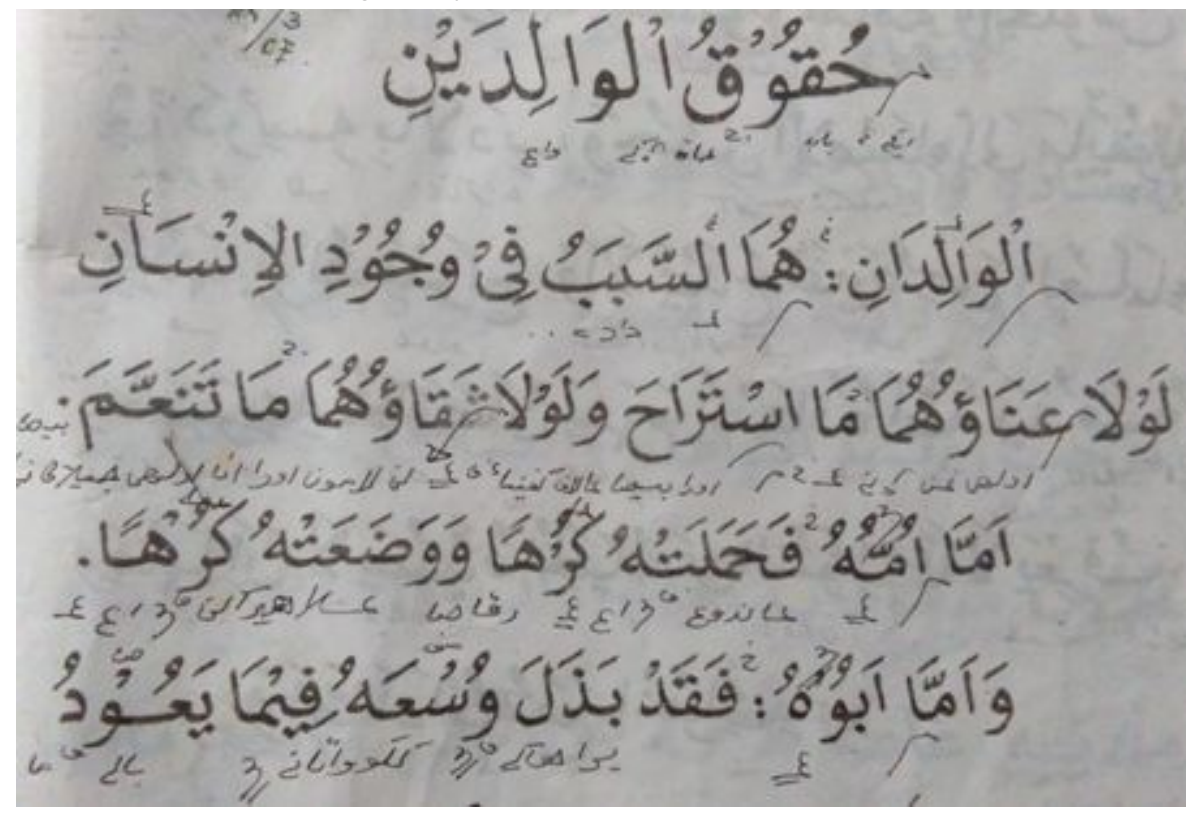

Gambar 1. Proses penterjemahan dalam pembacaan kitab kuning.

Kalimat setelah judul masih menggunaka kode mim yang menandakan kalimat tersebut merupakan kalimat nominal. Diatas kalimat al-walidani terdapat angka tiga terbalik yang memiliki ekor. Ini merupakan kode referensi (indek) untuk kalimat berikutnya. Hal ini mempermudah dalam proses penterjemahan. Seperti pada kata selanjutnya yaitu humaa, dibawah kata tersebut atau ditengahtengah antara humaa dan as sababu terdapat kode angka 3 terbalik. Jadi kata humaa tersebut merujuk pada kedua orang tua. Kata-kata dan frase pada kalimat pertama tidak semuanya diberi arti tepat 
dibawahnya dikarenakan santri sudah tahu arti tersebut sehingga tidak perlu untuk member arti semua kata atau frase yang ada dalam teks. Kalimat diatas "alwalidani humaa as sababu fi wujudil insani" ketika di baca sekaligus diterjemahkan oleh guru akan berbunyi "alwalidani utawi wong tuo loro iku humaa utawi wong tuo loro iku sababu dadi sebab fi wujudil insane ing ndalem wujude menungso" ini merupkan aktivitas word for word. Jika di indonesiakan secara word for word menjadi“ adapun orang tua adalah mereka (orang tua) yang menjadi sebab adanya manusia". Secara literal akan menjadi orang tua adalah lantaran wujudnya manusia. Allah menjadikan kedua orang tua sebagai lantaran wujudnya kehidupan manusia lainnya.

Sebaliknya dalam sorogan, kegiatan yang dijelaskan diatas dilakukan oleh santri yaitu mulai membaca, memberikan kode gramatikal dan arti serta menjelaskannya. Pada pembelajaran kitab ini, peserta didik/santri berada pada level sekolah menengah yaitu kelas XIdan XII yang telah mendapatkan pengajaran nahwu dan shorof (tata bahasa arab) pada level Jurumiyah. Menurut salah satu santri yang mengikuti pelajaran tersebut, proses sorogan biasanya merupakan suatu aktivitas pembuka pembelajaran. Maksudnya sebelum guru membahas materi baru, guru meminta salah satu santri untuk membaca dan memberi arti (maknani) materi sebelumnya dan salah satu siswa yang lainnya menjelaskannya. Dalam proses ini mereka membaca teks yang sudah ada maknanya. Pada tataran ini guru menekankan pada review materi dan membiasakan santri dengan sorogan. Selain itu, pada waktu yang khusus guru juga meminta santri untuk membaca kitab yang belum ada maknanya (kitab gundul). Seperti pada gambar 2 berikut ini:

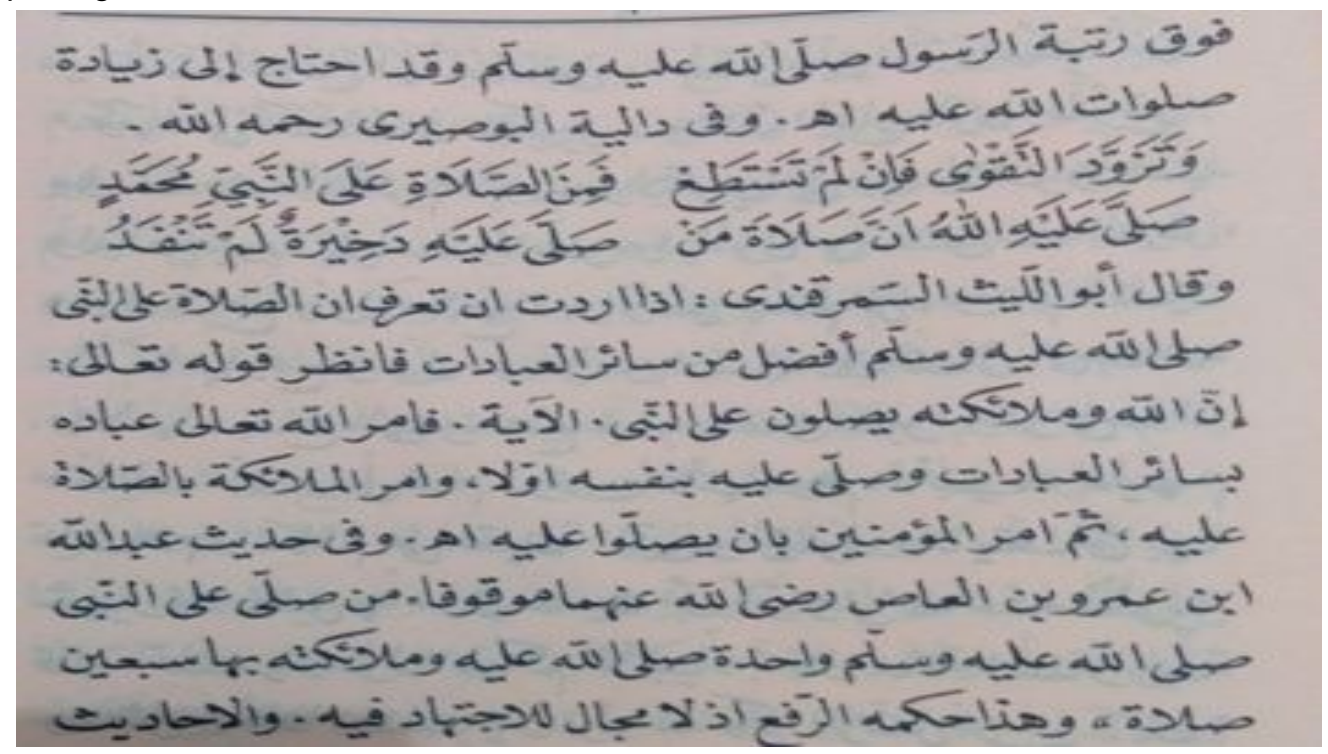

Gambar 2 Contoh tulisan kitab gundul

Gambar diatas merupakan contoh kitab gundul. Disebut gundul karena tidak ada harkat dan arti pada tiap kata ataupun frase dalam teks kecuali dalam teks syair. Dalam metode sorogan santri di minta membaca teks tersebut sesuai dengan gramatikal yang benar dan meberikan arti pada tiap kata atau frase dalam teks lalu menggunakan bahasa jawa/Indonesia kemudian menjelaskan apa yang dibaca berdasarkan pemahaman mereka. Proses tersebut merupakan pemberian arti word for word dan literal. Dan tentunya kegiatan ini tidak berhenti disitu saja, ada beberapa ustad yang meminta santri untuk menjelaskan apa yang sudah dibaca dalam bentuk tulisan sehingga lebih mudah dipahami dalam jangka waktu yang lama kemudian dilanjutkan dengan aktivitas berdiskusi tentang proses sorogan tadi, benar tidaknya penggunaan nahwu dan shorofnya serta isi dari apa yang dibaca.

\section{PENUTUP}

Kitab kuning merupakan bahan ajar yang wajib ada dalam pendidikan pesantren. Meskipun dalam perkembangannya banyak metode baru dalam pengajaran kitab kuning namun sebenarnya 
hanya modifikasi metode. Metode awal yang digunakan tetaplah bandongan dan sorogan kemudian mengarah pada metode diskusi atau syawir dalam istilah pesantren. Metode-metode tersebut disesuaikan dengan perkembangan peserta didiknya.

Sebenarnya metode bandongan dan sorogan merupakan metode dasar dalam metode pembelajaran apapun terkait dengan materi ajar yang berbahasa asing karena disini peserta didik di minta membaca dan mencari arti/pemahaman dalam teks yang secara tidak langsung siswa diminta menerjemah. Kedua metode tersebut menggambarkan proses penerjemahan tingkat awal yaitu word for word dan literal translation. Selama pendidik/guru mampu memodifikasi metode pembelajaran, tidak ada istilah metode mana yang baik dan mana yang buruk. Semua metode saling melengkapi dan menyesuaikan kebutuhan pendidik dan khususnya peserta didik.

\section{REFERENSI}

Hatim, B. \& Munday, J. (2008). Introducing Translation Studies:Theories and Application, 2nd edition. New York: Routledge.

Basnett, S .(2002). Translation Studies, $3^{\text {rd }}$ edition. New York: Routledge.

Brislin R. W.. (1976). Translation: Application and Research. New York: Gardner Press Inc.

Gay L. R, Mills, Geoffrer E \& Airasian, Peter W. (2012). Educational Research: Competencies for Analysis and Applications. Boston: Pearson educatation, Inc.

Çelik, P. G., \& Özcan, L. A. (2013). Determining proficiency level in foreign language teaching: the case of translation and interpretation students. Procedia-Social and Behavioral Sciences, 70, 288304.https://doi.org/10.1016/j.sbspro.2013.01.067

Dep.Agama RI. (2003). Pondok Pesantren dan Madrasah Diniyah. Jakarta: Departemen Agama RI.

Munday, J. (2008). Introducing Translation Studies: Theories and Applications, $2^{\text {nd }}$ ed.London: Routledge.

Newmark, P. (1981). Approach to Translation. Oxford: Pergamon Press, Ltd.

Newmark, P. (1988). A textbook of translation (Vol. 66). New York: Prentice hall.

Nida, E. A., \& Taber, C. R. (1969). The Theory and Practice of Translation. Leiden: EJ Brill.

PD Potren. (2008). Mihrab: Jurnal Pondok Pesantren. Ciputat: Departemen Agama RI.

Pekkanli, I. (2012). Translation and the contemporary language teacher. Procedia-Social and Behavioral Sciences, 46, 955-959.https://doi.org/10.1016/j.sbspro.2012.05.230

Robinson, D. (2007). Becoming a Translator: An introduction to Theory and Practice of Translation. $2^{\text {nd }}$ edition. New York: Routledge.

Wahid, A. (1999). Pesantren masa depan. Bandung: Pustaka Hidayah. 